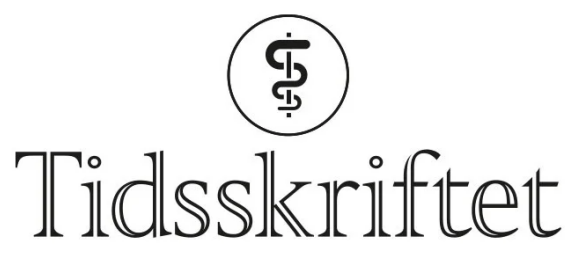

DEN NORSKE LEGEFORENING

\title{
Status for vaksineutvikling mot covid-19
}

KRONIKK

ARNE MICHAEL TAXT

arntax@ous-hf.no

Arne Michael Taxt er spesialist i barnesykdommer, lege i spesialisering og forsker ved Avdeling for mikrobiologi, Oslo universitetssykehus. Han har ph.d. i vaksineutvikling.

Forfatteren har fylt ut ICMJE-skjemaet og oppgir ingen interessekonflikter.

\section{GUNNVEIG GRØDELAND}

Gunnveig Grødeland er leder for forskningsgruppen Influenza and Adaptive Immunity ved Avdeling for immunologi og transfusjonsmedisin, Universitetet i Oslo og Oslo universitetssykehus.

Forfatteren har fylt ut ICMJE-skjemaet og oppgir ingen interessekonflikter.

\section{ANDREAS LIND}

Andreas Lind er spesialist i indremedisin, i infeksjonssykdommer og i medisinsk mikrobiologi. Han er overlege og enhetsleder ved Avdeling for mikrobiologi, er ansvarlig for virusdiagnostikk ved Oslo universitetssykehus, Ullevål, inkludert SARS-CoV-2-analysene, og har ph.d. i immunresponser ved terapeutisk hivvaksinering.

Forfatteren har fylt ut ICMJE-skjemaet og oppgir ingen interessekonflikter.

\section{FREDRIK MÜLLER}

Fredrik Müller er dr.med., spesialist i medisinsk mikrobiologi, professor ved Universitetet i Oslo og avdelingsleder ved Avdeling for mikrobiologi, Oslo universitetssykehus.

Forfatteren har fylt ut ICMJE-skjemaet og oppgir ingen interessekonflikter.

Pandemien forårsaket av SARS-CoV-2 har skapt en global humanitær og $\emptyset$ konomisk krise som vi ennå ikke ser noen løsning på. Det knyttes derfor enorme forhåpninger til en vaksine som beskytter mot sykdommen covid-19. Per august 2020 har Verdens helseorganisasjon registrert 173 vaksinekandidater under utvikling. Seks kandidater har nådd fase 3 -studier, og de første resultatene herfra forventes i løpet av høsten.

Verden opplever nå en pandemi forårsaket av severe acute respiratory syndrome coronavirus 2 (SARS-CoV-2), som hadde sitt utspring i Wuhan i Hubei-provinsen i Kina de siste månedene av $2019(\underline{1}, \underline{2})$. SARS-CoV-2 forårsaker sykdommen covid-19 (coronavirus disease 2019) og kan gi et svært variabelt klinisk bilde, fra mild øvre luftveisinfeksjon til alvorlig respirasjonssvikt med dødelig utfall. Eksakt letalitet (case fatality rate) av covid-19 er svært vanskelig å anslå, først og fremst fordi mange sannsynligvis gjennomgår infeksjon uten å bli testet. Letalitet påvirkes dessuten av alder, tilgjengelig behandling, underliggende sykdommer, overvekt med mer, men Verdens helseorganisasjon (WHO) antyder en generell letalitet for SARS-CoV-2 på rundt $0,5-1,0 \%$.

Forskjellige land har valgt å forholde seg til pandemien på svært ulike måter. I Norge ble store deler av samfunnet stengt ned 12. mars i år, mens Sveriges strategi våren 2020 var å beskytte sårbare grupper av befolkningen, men ellers la pandemien gå sin gang for å oppnå flokkimmunitet relativt raskt. Dessverre 
viser befolkningsstudier fra blant annet stockholmsområdet (3) og Spania (4) skuffende lav SARS-CoV-2seroprevalens selv i områder med stor smittespredning og høy dødelighet. Studier som inkluderer T-celleimmunitet, kan muligens forbedre dette bildet noe, ettersom cellulære immunresponser er påvist i smittede individer der det ikke er observert serokonversjon (5). Imidlertid ser det ut til at en strategi basert på å oppnå flokkimmunitet gjennom smitte med SARS-CoV-2, vil være en smertefull vei å gå. Vi kjenner ennå ikke rekkevidden av den norske strategien med stor grad av nedstengning av samfunnet, men det er opplagt at også denne strategien har hatt konsekvenser for helse og liv og har dessuten vært meget kostbar. Mot dette bakteppet av humanitær og økonomisk krise retter det seg store forventninger til utviklingen av en vaksine som beskytter mot covid-19.

\section{Biologi og antigener}

SARS-CoV-2 er et membrankledd positivkjedet RNA-virus i familien Coronaviridae. Det finnes mer enn 35 kjente koronavirus (므) som kan infisere ulike pattedyr, inkludert flaggermus, gris, storfe, kylling, hunder og katter (7.). Av disse kan syv i dag infisere mennesker. Virusfamilien deles videre inn i fire genera: alfa-, beta-, gamma- og deltakoronavirus. SARS-CoV-2 er et betakoronavirus, i likhet med to andre fryktede humanpatogene koronavirus med epidemisk potensial, nemlig SARS-CoV-1 og MERS-CoV (Middle-East respiratory syndrome coronavirus).

SARS-CoV-1 forårsaket i 2003 et stort globalt utbrudd som raskt spredde seg fra Guangdong-provinsen i Kina til minst 26 ulike land, med 8 og6 smittede og 774 dødsfall til følge (ㅁ). MERS-CoV har hittil stort sett gitt utbrudd begrenset til Den arabiske halvøy, med mer enn 2 ooo bekreftede tilfeller og mer enn 700 dødsfall (9.). Ytterligere fire koronavirus sirkulerer i befolkningen og gir varierende grad av forkjølelse og luftveisinfeksjoner, men sjelden svært alvorlig sykdom. Disse virusene, hvorav to er betakoronavirus (HCoV-HKU1 og HCoV-OC43) og to er alfakoronavirus (HCoV-229E og HCoV-NL63), antas å forårsake 15-30 \% av alle luftveisinfeksjoner (7.).

Genomet til SARS-CoV-2 er på ca. 30 ooo nukleotider og koder for fire strukturelle proteiner med benevningene pigg (spike)-protein (S), membranprotein (M), nukleokapsid (N) og konvolutt (envelope)protein (E) (므) (figur 1). I tillegg koder genomet for 23 ikke-strukturelle proteiner, inkludert en RNApolymerase $(\underline{10}, \underline{11})$. S-proteinene karakteriserer alle koronavirus, de dekker overflaten og fremstår som en krone (corona) ved elektronmikroskopi, noe som har gitt opphav til familienavnet Coronaviridae. Sproteinet hos SARS-CoV-2 inneholder et domene som interagerer med den humane reseptoren

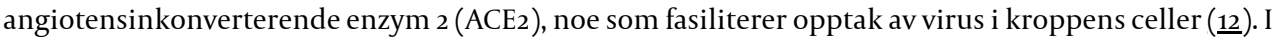
tillegg til SARS-CoV-2 benytter også SARS-CoV-1 og forkjølelsesviruset HCoV-NL63 denne opptaksmekanismen, men de andre koronavirusene gjør ikke det $(\underline{2}, \underline{13})$. ACE2 er uttrykt i epiteliale celler og endotelceller blant annet i lungevev, tarm, nyrer og hjerte (144).

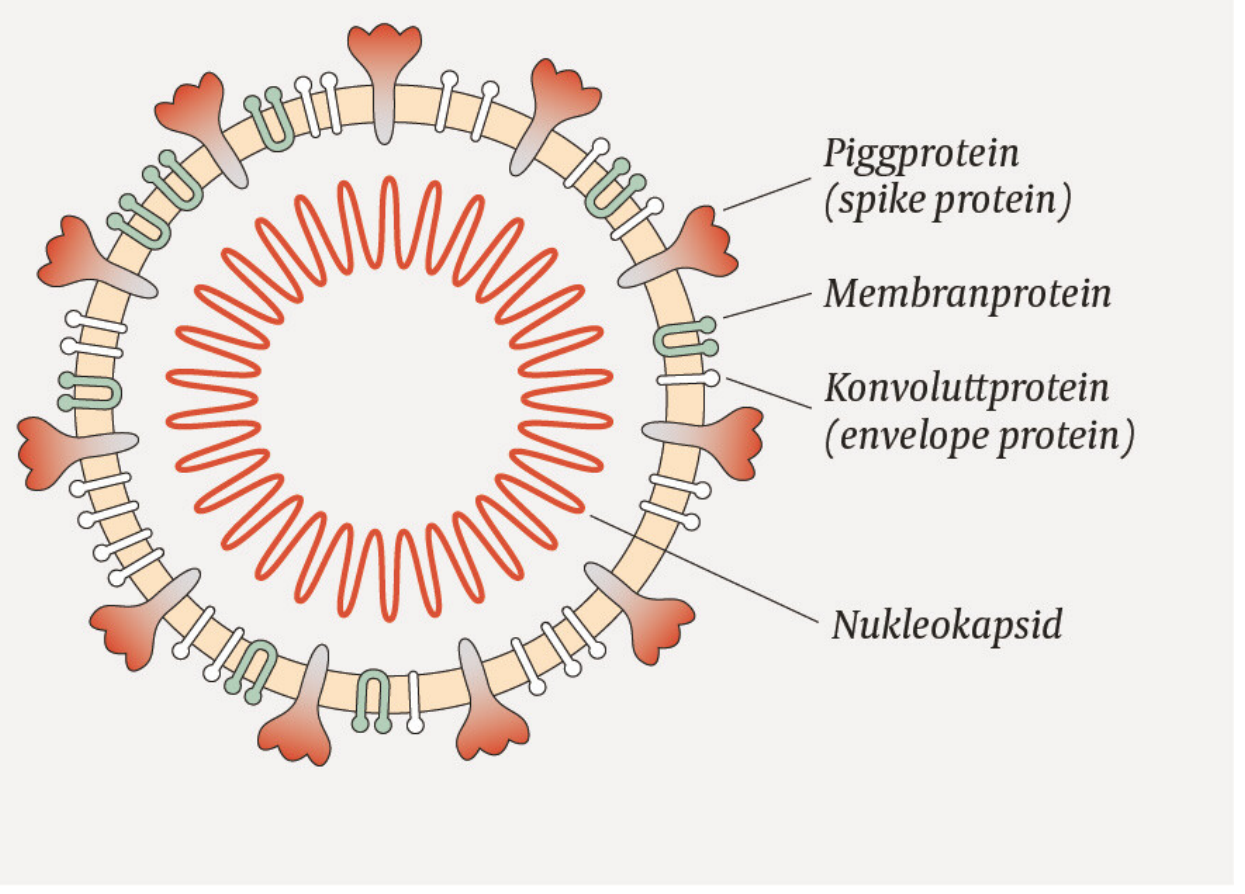


Figur 1 Skjematisk illustrasjon av SARS-CoV-2 med angivelse av de fire strukturelle proteinene pigg (spike)protein (S), membranprotein (M), konvolutt (envelope)-protein (E) og nukleokapsid (N). S-, M- og Eproteinene er forankret i lipidlaget som utgjør virusmembranen. N-proteinet er assosiert med viralt RNA på innsiden av membranen. Modifisert fra Desiree Ho, the Innovative Genomics Institute. CC BY-SA (https://creativecommons.org/licenses/by-sa/4.o).

S-proteinet er det primære antigenet for vaksineutvikling mot SARS-CoV-2 (figur 2), hvor målet er å generere en immunrespons som hindrer interaksjonen med ACE2. Det er derfor spesielt epitoper på den delen av S-proteinet som er i direkte kontakt med den humane reseptoren, det reseptorbindende domenet (RBD), man forsøker å etterlikne i et vaksinemolekyl. Det er nå veldokumentert at det genereres en immunrespons mot S-proteinet som følge av infeksjon med SARS-CoV-2, og in vitro-studier med rekonvalesenssera har vist at anti-S-antistoffer er i stand til å nøytralisere viruset i cellekultur og forhindre interaksjonen med ACE2.

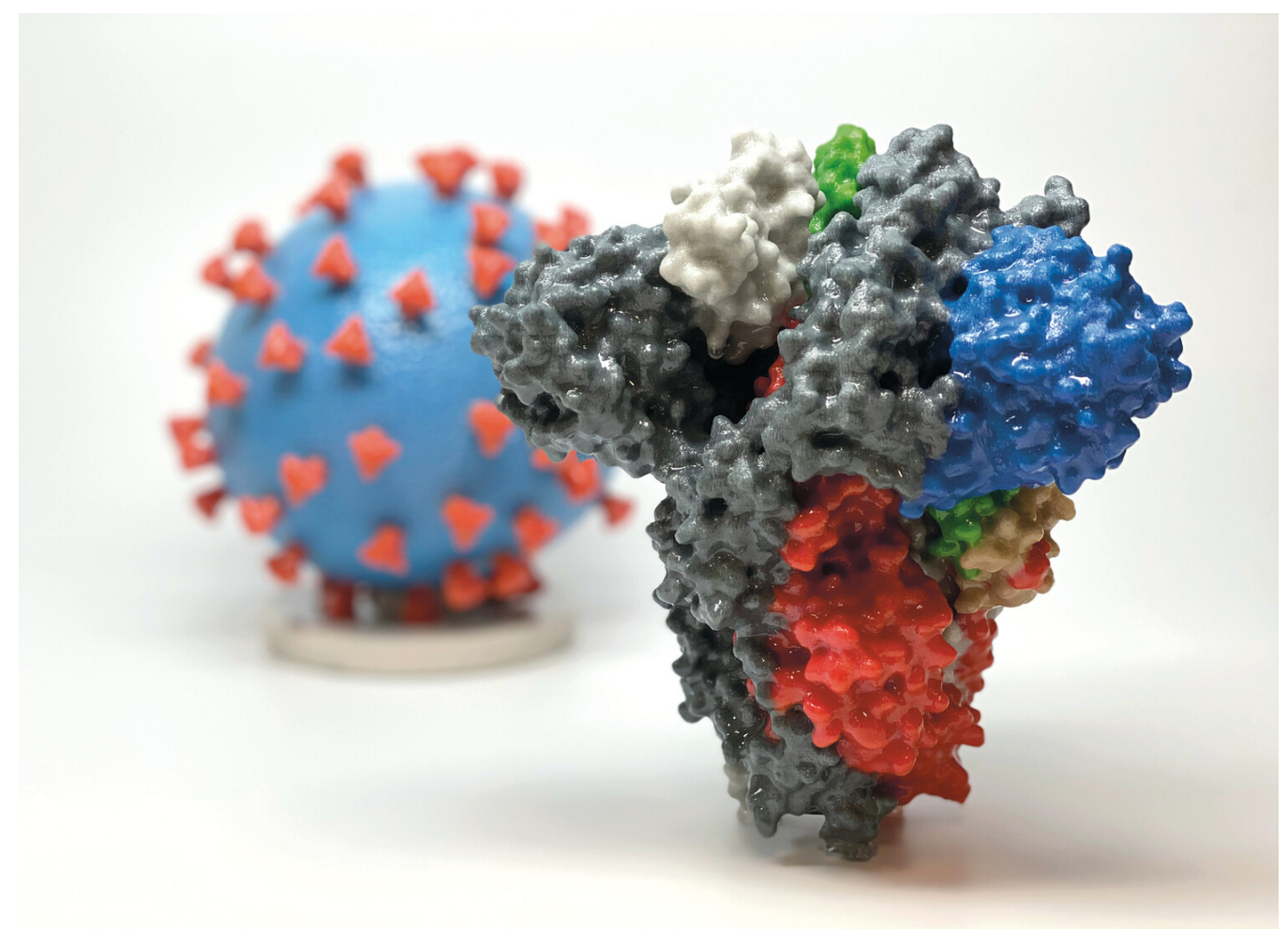

Figur 23 D-printet strukturmodell av pigg (spike)-proteinet (S) til SARS-CoV-2 sett fra siden. S-proteinet er det primære antigenet i vaksiner mot covid-19. Proteinet er et overflateeksponert glykoprotein sammensatt av tre identiske protomere og gjennomgår en strukturell endring når det binder til den humane reseptoren angiotensinkonverterende enzym 2. I figuren er én protomer gitt farge, der grønt angir det reseptorbindende domenet. I bakgrunnen sees en modell av en SARS-CoV-2- viruspartikkel. Fra National Institute of Allergy and Infectious Diseases (NIAID) / CC BY (https://creativecommons.org/licenses/by/2.o).

De tre andre strukturelle proteinene $(\mathrm{M}, \mathrm{N}$ og $\mathrm{E}$ ) betraktes ikke i dag som like viktige antigener i vaksinesammenheng, og relevansen av antistoffer mot disse er uklar. N-proteinet er ikke et overflateprotein, men assosiert med viralt RNA innenfor membranen som omkranser viruset. Imidlertid dannes antistoffer også mot N-proteinet under infeksjon med SARS-CoV-2 $(15, \underline{16})$, og tidligere vaksineutvikling mot SARS-CoV-1 har vist at N-proteinet kan generere T-celleresponser som gir immunologisk hukommelse (17.). Inklusjon av T-celleepitoper lokalisert på N-proteinet kan derfor være av betydning for å oppnå immunitet mot covid-19.

\section{Vaksiner mot covid-19}

Da det ble tydelig hvilken alvorlig global trussel SARS-CoV-2 utgjorde, var det flere institusjoner, vaksineprodusenter og forskningsgrupper som raskt gav seg i kast med utviklingen av en vaksine. I løpet av de første månedene av 2020 ble det dannet allianser og samarbeidsavtaler mellom store aktører i vaksinefeltet, både i akademia og i det kommersielle, og en rekke vaksinekandidater ble lansert. Flere av gruppene hadde tidligere erfaring med utvikling av vaksiner mot SARS-CoV-1 og MERS-CoV, og disse ble raskt tilpasset for anvendelse mot SARS-CoV-2. 
WHO holder en fortløpende oversikt over vaksinekandidater under utvikling ( $\underline{18})$, og per 28. august 2020 er det 142 registrerte vaksinekandidater i preklinisk stadium og 31 vaksinekandidater under klinisk utprøving (tabell 1).

\section{Tabell 1}

Vaksinekandidater under klinisk utprøving registrert av WHO august 2020, modifisert etter referanse 18 med lenker. Utfyllende informasjon om alle vaksinekandidatene er ikke tilgjengelig. Alle vaksinene har intramuskulær administrering med unntak av Inovio og Cadilas vaksinekandidater som administreres intradermalt. S-protein = pigg ( spike) -protein, $\mathrm{RBD}=$ det reseptorbindende domenet, $\mathrm{LNP}=$ lipidnanopartikler

\begin{tabular}{|c|c|c|c|c|c|c|c|}
\hline \multirow[t]{2}{*}{ Produsent og vaksinetype } & \multirow[t]{2}{*}{ Land } & \multirow{2}{*}{$\begin{array}{l}\text { Vektor / } \\
\text { molekyl }\end{array}$} & \multicolumn{2}{|c|}{ Antigen Navn } & \multicolumn{3}{|c|}{ Fase Fase Fase } \\
\hline & & & & & 1 & 2 & 3 \\
\hline \multicolumn{8}{|l|}{ Ikke-replikerende virus } \\
\hline $\begin{array}{l}\text { Universitetet i Oxford, } \\
\text { AstraZeneca }\end{array}$ & Storbritannia & $\begin{array}{l}\text { Sjimpanse } \\
\text { adenovirus }\end{array}$ & $\begin{array}{c}\mathrm{S}- \\
\text { protein }\end{array}$ & AZD1222 & $x$ & $\mathrm{x}$ & $\mathrm{x}$ \\
\hline $\begin{array}{l}\text { CanSino Biological / Beijing Inst } \\
\text { Biotech }\end{array}$ & Kina & $\begin{array}{l}\text { Humant } \\
\text { adenovirus } \\
\text { type } 5\end{array}$ & $\begin{array}{c}\mathrm{S}- \\
\text { protein }\end{array}$ & Ad5-nCoV & $\mathrm{x}$ & $\mathrm{x}$ & \\
\hline Gamaleya Research Institute & Russland & $\begin{array}{l}\text { Adenovirus } \\
\text { (Ad5 og } \\
\text { Ad26) }\end{array}$ & $\begin{array}{c}\text { S- } \\
\text { protein }\end{array}$ & Sputnik V & $x$ & $x$ & \\
\hline $\begin{array}{l}\text { Janssen Pharmaceutical } \\
\text { Companies }\end{array}$ & USA & Ad26COVS1 & $\begin{array}{c}\text { S- } \\
\text { protein }\end{array}$ & & $\mathrm{x}$ & & \\
\hline ReiThera/LEUKOCARE/Univercells & $\begin{array}{l}\text { Italia, } \\
\text { Tyskland, } \\
\text { Belgia }\end{array}$ & $\begin{array}{l}\text { Sjimpanse } \\
\text { adenovirus }\end{array}$ & $\begin{array}{c}\text { S- } \\
\text { protein }\end{array}$ & & $x$ & & \\
\hline \multicolumn{8}{|l|}{ DNA og RNA-vaksine } \\
\hline Moderna/NIAID & USA & $\begin{array}{l}\text { LNP- } \\
\text { encapsulated } \\
\text { mRNA }\end{array}$ & $\begin{array}{c}\text { S- } \\
\text { protein }\end{array}$ & mRNA-1273 & $x$ & $\mathrm{x}$ & $x$ \\
\hline Imperial College London & Storbritannia & $\begin{array}{l}\text { LNP- } \\
\text { nCoVsaRNA }\end{array}$ & $\begin{array}{c}\text { S- } \\
\text { protein }\end{array}$ & & $\mathrm{x}$ & & \\
\hline BioNTech/Fosun/Pharma/Pfizer & $\begin{array}{l}\text { Tyskland, } \\
\text { USA, mfl }\end{array}$ & 3 LNP-mRNAs & RBD & BNT162 & $x$ & $\mathrm{x}$ & $\mathrm{x}$ \\
\hline Curevac & Tyskland & mRNA & $\begin{array}{c}\text { S- } \\
\text { protein }\end{array}$ & & $x$ & & \\
\hline $\begin{array}{l}\text { People's Liberation Army, Military } \\
\text { Science,Walwax Biotech }\end{array}$ & Kina & mRNA-LNP & RBD & ARCoV & $\mathrm{x}$ & & \\
\hline Inovio Pharmaceuticals / IVI & USA & DNA plasmid & $\begin{array}{c}\text { S- } \\
\text { protein }\end{array}$ & INO-4800 & $\mathrm{x}$ & $\mathrm{x}$ & \\
\hline Genexine Consortium & Sør Korea & DNA & $\begin{array}{c}\text { S- } \\
\text { protein }\end{array}$ & GX-19 & $x$ & & \\
\hline $\begin{array}{l}\text { Osaka University / AnGes / Takara } \\
\text { Bio }\end{array}$ & Japan & $\begin{array}{l}\text { DNA plasmid } \\
\text { + adjuvant }\end{array}$ & & & $\mathrm{x}$ & $\mathrm{x}$ & \\
\hline Cadila Healthcare Ltd. & India & DNA plasmid & & ZyCoV-D & $x$ & & \\
\hline Arcturus/Duke-NUS & $\begin{array}{c}\text { USA, } \\
\text { Singapore }\end{array}$ & mRNA & & & $\mathrm{x}$ & & \\
\hline \multicolumn{8}{|l|}{ Proteinbasert vaksine } \\
\hline Novavax & USA & $\begin{array}{l}\text { Glykoprotein } \\
\text { nanopartikkel }\end{array}$ & $\begin{array}{c}\text { S- } \\
\text { protein }\end{array}$ & $\begin{array}{l}\text { NVX- } \\
\text { CoV23723 }\end{array}$ & $x$ & $\mathrm{x}$ & \\
\hline
\end{tabular}




\begin{tabular}{|c|c|c|c|c|c|c|c|}
\hline \multirow[t]{2}{*}{ Produsent og vaksinetype } & \multirow[t]{2}{*}{ Land } & \multirow{2}{*}{$\begin{array}{l}\text { Vektor / } \\
\text { molekyl }\end{array}$} & \multicolumn{2}{|c|}{ Antigen Navn } & \multicolumn{3}{|c|}{ Fase Fase Fase } \\
\hline & & & & & & 2 & 3 \\
\hline $\begin{array}{l}\text { Clover Biopharma } \\
\text { Inc./GSK/Dynavax }\end{array}$ & Kina, USA & $\begin{array}{l}\text { Trimeric } \\
\text { subunit S- } \\
\text { protein }\end{array}$ & $\begin{array}{c}\mathrm{S}- \\
\text { protein }\end{array}$ & SCB-2019 & $x$ & & \\
\hline $\begin{array}{l}\text { Anhui Zhifei Longcom, Inst } \\
\text { Microbiology China, CAS }\end{array}$ & Kina & $\begin{array}{l}\text { RBD-dimer } \\
\text { med adjuvans }\end{array}$ & RBD & & $x$ & & \\
\hline Vaxine Pty Ltd/Medytox & $\begin{array}{l}\text { Australia, } \\
\text { Sør-Korea }\end{array}$ & $\begin{array}{l}\text { S-protein + } \\
\text { Advax } \\
\text { adjuvant }\end{array}$ & $\begin{array}{c}\mathrm{S}- \\
\text { protein }\end{array}$ & & $x$ & & \\
\hline $\begin{array}{l}\text { University of Queensland / CSL - } \\
\text { Seqirus }\end{array}$ & Australia & $\begin{array}{l}\text { Molecular } \\
\text { clamp, S- } \\
\text { protein }\end{array}$ & $\begin{array}{c}\mathrm{S}- \\
\text { protein }\end{array}$ & & $x$ & & \\
\hline Medicago Inc. & Kanada & $\begin{array}{l}\text { Virus- } \\
\text { liknende } \\
\text { partikkel }\end{array}$ & & & $x$ & & \\
\hline Kentucky Bioprocessing & USA & RBD-basert & RBD & & $x$ & & \\
\hline Medigen Vaccine/NIAID/Dynavax & USA, Taiwan & $\begin{array}{l}\text { S-2P protein + } \\
\text { CpG } 1018\end{array}$ & & & $\mathrm{x}$ & & \\
\hline $\begin{array}{l}\text { State Research Centre of Virology } \\
\text { and Biotechnology VECTOR }\end{array}$ & Russland & Peptides (?) & & EpiVacCorona & $x$ & & \\
\hline Instituto Finlay de Vacunas & Cuba & RBD & RBD & Soberana 1 & $x$ & & \\
\hline \multicolumn{8}{|l|}{ Inaktivert virus } \\
\hline Wuhan Institute / Sinopharm & Kina & $\begin{array}{l}\text { Inaktivert } \\
\text { SARS-CoV-2 }\end{array}$ & $\begin{array}{l}\text { Hele } \\
\text { viruset }\end{array}$ & $\begin{array}{l}\text { COVID-19 } \\
\text { vaccine }\end{array}$ & $x$ & $x$ & $\mathrm{x}$ \\
\hline $\begin{array}{l}\text { Beijing Institute of Biological } \\
\text { Products / Sinopharm }\end{array}$ & Kina & $\begin{array}{l}\text { Inaktivert } \\
\text { SARS-CoV-2 }\end{array}$ & $\begin{array}{l}\text { Hele } \\
\text { viruset }\end{array}$ & Sinovac & $x$ & $x$ & $x$ \\
\hline Sinovac & Kina & $\begin{array}{l}\text { Inaktivert } \\
\text { SARS-CoV-2 + } \\
\text { alum }\end{array}$ & $\begin{array}{l}\text { Hele } \\
\text { viruset }\end{array}$ & CoronaVac & $x$ & $x$ & $\mathrm{x}$ \\
\hline $\begin{array}{l}\text { Inst. of Medical Biology, Chinese } \\
\text { Academy of Med. Sciences }\end{array}$ & Kina & $\begin{array}{l}\text { Inaktivert } \\
\text { SARS-CoV-2 }\end{array}$ & $\begin{array}{c}\text { Hele } \\
\text { viruset }\end{array}$ & & $x$ & & \\
\hline Bharat Biotech & India & $\begin{array}{l}\text { Inaktivert } \\
\text { SARS-CoV-2 }\end{array}$ & $\begin{array}{c}\text { Hele } \\
\text { viruset }\end{array}$ & & $x$ & $x$ & \\
\hline \multicolumn{8}{|l|}{ Levende, svekket virus } \\
\hline $\begin{array}{l}\text { Institute Pasteur, Themis, Univ. Of } \\
\text { Pittsburg, Merck Sharp \&Dome }\end{array}$ & $\begin{array}{l}\text { Frankrike, } \\
\text { USA }\end{array}$ & $\begin{array}{l}\text { Meslingvirus, } \\
\text { rekombinant }\end{array}$ & $\begin{array}{c}\text { S- } \\
\text { protein }\end{array}$ & & $x$ & & \\
\hline
\end{tabular}

\section{IKKE-REPLIKERENDE VIRUSVAKSINER}

Denne typen vaksiner er basert på virus som er levende, men som ikke er i stand til å replikere i mennesker. Generelt gir denne type vaksiner opphav til robuste humorale og cellulære immunresponser. For å unngå at viruset replikerer i mennesker kan man benytte et virus som ikke er humanpatogent, eller et humanpatogent virus som er modifisert slik at det ikke lenger er i stand til å replikere.

En av de vaksinekandidatene som har kommet lengst, og som nå er i fase 3 av klinisk utprøving (tabell 2) (19), utvikles i samarbeid mellom Universitetet i Oxford i Storbritannia og AstraZeneca, og går under navnet AZD1222. Denne vaksinen benytter et adenovirus fra sjimpanser som vektor (ChAdOx1) og er blitt modifisert til å uttrykke S-proteinet fra SARS-CoV-2. Adenovirusvektoren ChAdOx1 har tidligere blant annet blitt benyttet i vaksineutvikling mot MERS, og en vaksine som presenterte S-proteinet fra MERS ble rapportert som både trygg og med evne til å indusere relevante immunresponser (dvs. var immunogen) $\mathrm{i}$ en fase 1-studie ( $\underline{20})$. Vaksinegruppen hadde derfor tilgjengelig en plattform for utvikling av vaksiner mot koronavirus og kunne raskt tilpasse denne mot SARS-CoV-2. 
Tabell 2

Kliniske faser av vaksineutvikling

\begin{tabular}{|ccccc|}
\hline Stadium & Mål & Primærutfall & $\begin{array}{c}\text { Deltakere, typisk } \\
\text { antall }\end{array}$ & Design \\
\hline Fase 1 & $\begin{array}{c}\text { Første gang i } \\
\text { menneske, } \\
\text { doseutprøving }\end{array}$ & $\begin{array}{c}\text { Sikkerhet og } \\
\text { immunogenisitet }\end{array}$ & $\begin{array}{c}\text { Voksne frivillige, 10-100 } \\
\text { deltakere }\end{array}$ & $\begin{array}{c}\text { Kontrollert eller ikke- } \\
\text { kontrollert }\end{array}$ \\
\hline Fase 2 & $\begin{array}{c}\text { Første evaluering i } \\
\text { målpopulasjon }\end{array}$ & $\begin{array}{c}\text { Sikkerhet og } \\
\text { immunogenisitet }\end{array}$ & $\begin{array}{c}\text { Målpopulasjon, 50-500 } \\
\text { deltakere }\end{array}$ & $\begin{array}{c}\text { Randomisert, } \\
\text { dobbeltblindet, kontrollert } \\
\text { med placebo }\end{array}$ \\
\hline Fase 3 & $\begin{array}{c}\text { Full evaluering i } \\
\text { målpopulasjon }\end{array}$ & $\begin{array}{c}\text { Beskyttende effekt, } \\
\text { sikkerhet }\end{array}$ & $\begin{array}{c}\text { Målpopulasjon, 1000- } \\
\text { 150 000 deltakere }\end{array}$ & $\begin{array}{c}\text { Randomisert, } \\
\text { dobbeltblindet, kontrollert } \\
\text { med placebo }\end{array}$ \\
\hline
\end{tabular}

${ }^{1}$ Med evne til å indusere målbare relevante immunresponser

Resultater fra dyrefors $\emptyset \mathrm{k}$ har nå vist at AZD1222 er immunogen i mus og at rhesusaper (makaker) ble

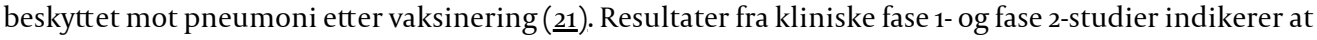
vaksinasjon kan danne robuste antistoffresponser etter én dose, men at vaksinering i enkelte individer vil

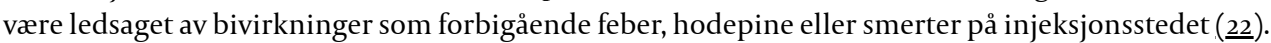
Antistoffdataene gir grunn til optimisme rundt vaksinens evne til å danne beskyttende immunitet, og fase 3-studier pågår nå i England, India, Brasil, USA og Sør-Afrika.

«Det vi imidlertid ikke vet noe om før data fra fase 3-studiene kommer, er om disse immunresponsene gir beskyttelse mot covid-19"

En annen vaksinekandidat i denne gruppen utvikles i Kina av CanSino Biologics i samarbeid med Beijing Institute of Biotechnology. Vaksinen benytter humant adenovirus type 5 som vektor, og er modifisert til å uttrykke S-proteinet fra SARS-CoV-2. Denne vektoren har tidligere vært benyttet til ebolavaksinen Ad5EBOV (23) og viste da en god sikkerhetsprofil ved fase 1- og fase 2-studier. CanSino publiserte nylig resultater fra fase 1-studien med 108 deltakere for vaksinen mot SARS-CoV-2. De fant at vaksinen dannet gode nivåer av både nøytraliserende antistoff og spesifikke T-celler (24).). I likhet med AZD1222 ga også denne vaksinen bivirkninger i form av smerter på innstikksstedet og feber, men ingen alvorlige hendelser ble rapportert. Strategien med å bruke det humane forkjølelsesviruset adenovirus type 5 som vektor er blitt kritisert, fordi en del av befolkningen kan forventes å ha preeksisterende immunitet mot vektoren og dermed nøytralisere vaksinen før det har dannet seg en immunrespons mot S-proteinet $(23,25)$.

Også i Russland er en adenovirusbasert vaksine under utvikling, i regi av The Gamaleya Research Institute of Epidemiology and Microbiology i Moskva. Lite informasjon er foreløpig tilgjengelig, men vaksinen, Sputnik V, skal ha vært igjennom fase 1- og 2-studier, og det er nå igangsatt fase 3-utprøving. Sputnik V ble gjenstand for kontroverser da Russland annonserte at vaksinen som den første i verden var registrert og godkjent, før det var gjennomført en fase 3-studie. Russiske nyheter melder nå at det gjennomføres en postregistreringsstudie, hvor titusener av helsepersonell er inkludert.

NUKLEOTIDVAKSINER

Nukleotidvaksiner består av enten DNA eller RNA som koder for de vaksineantigenene som ønskes uttrykt, og det er de humane cellene hos verten som omsetter nukleinsyresekvensene til virusproteiner. Kliniske studier gjennom 20 år har vist at nukleotidvaksiner er trygge, men det finnes per i dag likevel ingen vaksiner av denne typen som er godkjent for humant bruk. Grunnen er at det er vanskelig å få nukleotidvaksiner til å danne kraftige nok immunresponser til at det dannes immunologisk hukommelse. Til tross for dette er hele 10 av de 31 covid-19-vaksinene som har nådd kliniske studier, nukleotidvaksiner. Ingen andre vaksineformater kan produseres like raskt som nukleotidvaksiner, og den syntetiske produksjonen (ingen levende virus eller strukturelle epitoper involvert) er velegnet for 
storskalaproduksjon. De siste årene har store fremskritt innen vaksinelevering og vektordesign gitt tro på at også nukleotidvaksiner kan indusere god immunologisk hukommelse. SARS-CoV-2-pandemien kan dermed komme til å representere gjennomslaget for nukleotidvaksiner til humant bruk.

Utfyllende informasjon for alle nukleotidvaksinene som nå er under utprøving er ikke tilgjengelig, men de fleste koder for hele eller deler av S-proteinet til SARS-CoV-2. Flere av vaksineprodusentene har tidligere klinisk erfaring med denne typen vaksiner, blant annet mot ebolavirus, lassavirus, denguevirus og MERS. Hvor potent immunrespons man kan oppnå med nukleotidvaksiner, er ennå uklart, og det kan være nødvendig med gjentatte doser for å oppnå beskyttende immunresponser.

Den vaksinekandidaten som har kommet lengst av nukleotidvaksinene utvikles av bioteknologifirmaet Moderna i samarbeid med National Institutes of Health i USA. Vaksinekandidaten består av mRNA som koder for S-proteinet innpakket i lipidnanopartikler. Resultater fra fase 1-studien med 45 deltakere ble nylig publisert (므), og vaksinen ga solide immunresponser hos deltakerne. Det ble imidlertid også rapportert om bivirkninger, særlig for den høyeste dosen, men ingen alvorlige. Fase 2-studien er nylig avsluttet, og rekruttering av 30 ooo individer til storskalaeffektstudier i fase 3 pågår.

Tre andre viktige aktører som også arbeider med nukleotidbaserte vaksiner er Inovio, Imperial College London og det tyske selskapet CureVac. Alle disse har bred erfaring fra tidligere med sine nukleotidbaserte vaksineplattformer, og de er godt i gang med kliniske studier. Foreløpig er ingen kliniske data vitenskapelig publisert.

PROTEINBASERTE VAKSINER

Disse vaksinene består av ett eller flere utvalgte proteiner som antas å være nøkkelantigener og inneholder da epitoper som kan gi opphav til beskyttende immunitet. Med tanke på produksjon er det her en fordel at man ikke må arbeide med levende virus, og proteinvaksiner kan være godt egnet for masseproduksjon. Korrekt struktur av de vaksineproteinene som produseres, er avgjørende for å sikre at immunresponser induseres mot epitoper som finnes naturlig på viruset. Proteinvaksiner gir generelt en svakere immunrespons enn levende vaksiner, og det vil ofte være behov for gjentatte doser og inklusjon av adjuvans - stoffer som tilsettes for å bedre immunresponsen.

I skrivende stund er ti proteinvaksinekandidater i kliniske studier, med det amerikanske firmaet Novavax som ledende aktør. Deres vaksinekandidat, som også er basert på S-proteinet, har vært utprøvd i fase 1studier i Australia og er nå i fase 2. En annen aktør verdt å nevne er kanadiske Medicago som produserer en vaksine basert på såkalte virusliknende partikler. Dette er proteinbaserte strukturer som etterlikner formen på et virus, men som mangler virusets genom, slik at det ikke kan replikere. Proteinene er her produsert i blader fra en plante i tobakksfamilien og etterlikner S-proteinet til SARS-CoV-2. Medicago har erfaring med denne vaksineplattformen fra utvikling av influensavaksiner.

INAKTIVERTE VIRUSVAKSINER

Prinsippet med å isolere en mikrobe, inaktivere den for så å injisere den som vaksine, ble etablert av vaksinepionéren Louis Pasteur på 180o-tallet. Det har gitt oss mange av de vaksinene som er i bruk i dag. Fem produsenter har nå vaksinekandidater under klinisk utprøving der dette prinsippet er anvendt på SARS-CoV-2. Disse vaksinene inneholder antigener fra hele viruset, men man risikerer at inaktiveringsprosessen (som gjerne er kjemisk) kan ødelegge viktige epitoper. En utfordring i produksjonsprosessen er at man arbeider med til dels store mengder av det patogene viruset forut for inaktiveringen, noe som kan vanskeliggjøre rask og trygg oppskalering av vaksineproduksjon.

Ledende i denne gruppen er det kinesiske firmaet Sinovac, som har kommet til fase 3 i utprøvingen av sin vaksinekandidat. Firmaet har erfaring fra tidligere vaksineutvikling, blant annet mot SARS-CoV-1, og publiserte tidlig lovende prekliniske resultater for sin SARS-CoV-2-vaksinekandidat fra dyrefors $\emptyset \mathrm{k}$ med mus, rotter og primater (27.). Det er foreløpig ikke publisert data fra de humane studiene.

LEVENDE, SVEKKEDE VIRUSVAKSINER

Denne typen vaksiner er godt etablert og benyttes blant annet i det norske barnevaksinasjonsprogrammet i form av MMR-vaksinen, som består av svekket meslingvirus, kusmavirus og rubellavirus. Vaksinegruppen ved Pasteurinstituttet har benyttet svekket meslingvirus som vektor for å uttrykke S-proteinet til SARS$\mathrm{CoV}-2$, og denne vaksinekandidaten er nå i første fase av klinisk utprøving. Flere av vaksinekandidatene i preklinisk stadium benytter en tilsvarende strategi.

\section{Andre aspekter av vaksineutvikling}

Utviklingen av en ny vaksine er en svært kompleks og dyr prosess som vanligvis tar mange år, men som her foregår i ekspressfart med mange parallelle prosesser og enorm økonomisk støtte $(\underline{28})$. Noen viktige variabler som må studeres for hver vaksinekandidat, er dosering av antigener, doseringsregime, administrasjonsform og eventuell bruk av adjuvans. Av stor betydning er også inngående analyser av 
mulige bivirkninger, noe som ofte henger tett sammen med dosering av vaksinen. Her er det begrenset hvor mye man kan redusere tidsrammen, ettersom økende trygghet med henblikk på å utelukke bivirkninger kommer med lengre observasjonstid og store fase 3-studier.

At bivirkninger er en reell utfordring, finnes det flere eksempler på. Mest fryktet er såkalt antistoffavhengig forsterkning (antibody-mediated enhancement), som innebærer at vaksinerte individer kan få økt risiko for alvorlig sykdom hvis de blir smittet. En slik effekt er blitt observert tidligere blant annet for vaksinekandidater mot respiratorisk syncytialvirus (RS-virus) og denguevirus (299,30). Dyrefors $\varnothing \mathrm{k}$ indikerer at dette også kan være en utfordring for vaksineutvikling mot koronavirus (31-33). Det er derfor viktig å teste mange ulike vaksineformater, og helst også med ulike antigener, slik at vi til slutt kan velge effektive vaksiner som induserer en trygg type immunrespons.

\section{«Det er en trend at man utvikler universelle vaksinesystemer hvor nye antigener raskt kan integreres for å tjene som vaksine i møte med en ny epidemisk trussel»}

Oppskalering og storskalaproduksjon av en vaksine er i seg selv en enorm utfordring når det er snakk om flere hundre millioner, kanskje milliarder, av doser. Presisjon og kvalitet må sikres i alle ledd, inkludert korrekt transport, oppbevaring og håndtering til vaksinen når frem til det individet som skal vaksineres. Politisk dragkamp kan forventes når de første vaksinedosene skal fordeles. Flere internasjonale organisasjoner vil her spille en viktig rolle, inkludert WHO, vaksinealliansen GAVI og CEPI (The Coalition for Epidemic Preparedness Innovations). Sistnevnte, som er etablert i Norge og har hovedkvarter i Oslo, gir stor $\emptyset$ konomisk støtte til flere av de ledende vaksinekandidatene og arbeider for rettferdig global fordeling av vaksiner. Amerikanske myndigheter har lansert et eget initiativ kalt Operation Warp Speed, som gir stor $\emptyset$ konomisk støtte til utvalgte vaksinekandidater og primært skal sikre amerikanske interesser.

Om de ulike stadiene av klinisk utprøving ( tabell 2) bemerkes det at fase 1-studier typisk gjennomføres med unge, friske voksne, mens det er den eldste aldersgruppen som er mest utsatt for alvorlig forløp av covid-19. Eldre responderer også ofte dårligere på vaksinering. Hittil er klinisk utprøving primært utført blant unge voksne, så effekt av de ulike vaksinene hos eldre vet vi ennå lite om. Selv om immunresponser evalueres i fase 1- og fase 2-studier, er det først i storskala fase 3-studier at man undersøker i hvilken grad vaksinen beskytter mot sykdom.

\section{Konklusjon}

Utviklingen av teknikker for vaksinering er en av de største og viktigste bragdene i medisinens historie. Iblant er dette så effektivt at befolkningen glemmer hvor stor betydning vaksinene har. Under den humanitære og økonomiske katastrofen som nå utspiller seg som følge av den pågående pandemien, knytter det seg intens oppmerksomhet og store forhåpninger til en effektiv vaksine mot covid-19. I skrivende stund er minst 173 vaksinekandidater under utvikling og seks kandidater har nådd fase 3-studier.

Det foreløpige bildet er at flere kandidater er blitt vurdert som trygge nok til humant bruk og at disse genererer relevante immunresponser mot SARS-CoV-2. Det vi imidlertid ikke vet noe om før data fra fase 3studiene kommer, er om disse immunresponsene gir beskyttelse mot covid-19. Historien har lært oss at mange lovende vaksinekandidater skuffer når den beskyttende effekten evalueres i store kliniske studier. Varigheten av en eventuell immunitet kan det foreløpig kun spekuleres om.

\section{«Flere kandidater er blitt vurdert som trygge nok til humant bruk og genererer relevante immunresponser mot SARS-CoV-2»}

Det siste halvårets prestasjoner på vaksinefronten har vist at når nøden er stor nok og verdenssamfunnet fokuserer sine krefter på ett definert mål, kan prosesser som vanligvis tar mange år komprimeres til noen få måneder. Delvis skyldes dette at regulatoriske myndigheter har kastet seg rundt i saksbehandling, delvis skyldes det enorme økonomiske ressurser og stor økonomisk risikovilje, men en viktig årsak er også såkalte "plattformteknologier» i vaksinebransjen. Det er en trend at man utvikler universelle vaksinesystemer hvor nye antigener raskt kan integreres for å tjene som vaksine i møte med en ny epidemisk trussel.

Er det noe pandemien har lært oss, så er det at satsing på epidemiberedskap bør være en høy prioritet for å kunne opprettholde det levesettet, den levestandarden og den bevegelsesfriheten vi ønsker. Pandemien forårsaket av SARS-CoV-2 er ikke den første, og helt sikkert ikke den siste, som rammer oss. Virusene vil fortsette å komme, og løsningen vil ofte være en vaksine. 


\section{LITTERATUR}

1. World Health Organization. WHO announces COVID-19 outbreak a pandemic. https://www.euro.who.int/en/healthtopics/health-emergencies/coronavirus-covid-19/news/news/2020/3/who-announces-covid-19-outbreak-a-pandemic Lest 2.9.2020

2. Zhou P, Yang XL, Wang XG et al. A pneumonia outbreak associated with a new coronavirus of probable bat origin. Nature 2020; 579: 270-3. [PubMed][CrossRef]

3. Folkhälsomyndigheten. Förekomsten av covid-19 i Sverige 21-24 april och 25-28 maj 2020.

https://www.folkhalsomyndigheten.se/publicerat-material/publikationsarkiv/f/forekomsten-av-covid-19-i-sverige-21-24april-och-25-28-maj-2020/ Lest 2.9.2020.

4. Pollán M, Pérez-Gómez B, Pastor-Barriuso R et al. Prevalence of SARS-CoV-2 in Spain (ENE-COVID): a nationwide, population-based seroepidemiological study. Lancet 2020;396: 535-44. [PubMed][CrossRef]

5. Grifoni A, Weiskopf D, Ramirez SI et al. Targets of T cell responses to SARS-CoV-2 coronavirus in humans with COVID19 disease and unexposed individuals. Cell 2020; 181: 1489-1501.e15. [PubMed][CrossRef]

6. Shereen MA, Khan S, Kazmi A et al. COVID-19 infection: Origin, transmission, and characteristics of human coronaviruses. J Adv Res 2020; 24: 91-8. [PubMed][CrossRef]

7. Fehr AR, Perlman S. Coronaviruses: an overview of their replication and pathogenesis. Methods Mol Biol 2015; 1282:123. [PubMed][CrossRef]

8. Christian MD, Poutanen SM, Loutfy MR et al. Severe acute respiratory syndrome. Clin Infect Dis 2004; 38: 1420-7. [PubMed][CrossRef]

9. Chafekar A, Fielding BC. MERS-CoV: Understanding the Latest Human Coronavirus Threat. Viruses 2018; 10: 93. [PubMed][CrossRef]

10. Wu A, Peng Y, Huang B et al. Genome composition and divergence of the novel coronavirus (2019-nCoV) originating in China. Cell Host Microbe 2020; 27:325-8. [PubMed][CrossRef]

11. Wang Y, Anirudhan V, Du R et al. RNA-dependent RNA polymerase of SARS-CoV-2 as a therapeutic target. J Med Virol 2020; jmv.26264. [PubMed][CrossRef]

12. Hoffmann M, Kleine-Weber H, Schroeder S et al. SARS-CoV-2 cell entry depends on ACE2 and TMPRSS2 and is blocked by a clinically proven protease inhibitor. Cell 2020; 181: 271-280.e8. [PubMed][CrossRef]

13. Hofmann H, Pyrc K, van der Hoek L et al. Human coronavirus NL63 employs the severe acute respiratory syndrome coronavirus receptor for cellular entry. Proc Natl Acad Sci U S A 2005; 102: 7988-93. [PubMed][CrossRef]

14. Yan R, Zhang Y, Li Y et al. Structural basis for the recognition of SARS-CoV-2 by full-length human ACE2. Science 2020; 367: 1444-8. [PubMed][CrossRef]

15. To KK, Tsang OT, Leung WS et al. Temporal profiles of viral load in posterior oropharyngeal saliva samples and serum antibody responses during infection by SARS-CoV-2: an observational cohort study. Lancet Infect Dis 2020; 20 : 565-74. [PubMed][CrossRef]

16. Sun B, Feng Y, Mo X et al. Kinetics of SARS-CoV-2 specific IgM and IgG responses in COVID-19 patients. Emerg Microbes Infect 2020; 9: 940-8. [PubMed][CrossRef]

17. Peng H, Yang LT, Wang LY et al. Long-lived memory T lymphocyte responses against SARS coronavirus nucleocapsid protein in SARS-recovered patients. Virology 2006; 351: 466-75. [PubMed][CrossRef]

18. World Health Organization. Draft landscape of COVID-19 candidate vaccines.

https://www.who.int/publications/m/item/draft-landscape-of-covid-19-candidate-vaccines Lest 28.8.2020.

19. Farrington CP, Miller E. Vaccine trials. Mol Biotechnol 2001; 17: 43-58. [PubMed][CrossRef]

20. Folegatti PM, Bittaye M, Flaxman A et al. Safety and immunogenicity of a candidate Middle East respiratory syndrome coronavirus viral-vectored vaccine: a dose-escalation, open-label, non-randomised, uncontrolled, phase 1 trial. Lancet Infect Dis 2020; 20: 816-26. [PubMed][CrossRef]

21. van Doremalen N, Lambe T, Spencer A et al. ChAdOx1 nCoV-19 vaccination prevents SARS-CoV-2 pneumonia in rhesus macaques. bioRxiv 2020; 2020.05.13.093195. [PubMed][CrossRef]

22. Folegatti PM, Ewer KJ, Aley PK et al. Safety and immunogenicity of the ChAdOx1 nCoV-19 vaccine against SARS-CoV2: a preliminary report of a phase 1/2, single-blind, randomised controlled trial. Lancet 2020;396: 467-78. [PubMed] [CrossRef]

23. Wu L, Zhang Z, Gao H et al. Open-label phase I clinical trial of Ad5-EBOV in Africans in China. Hum Vaccin Immunother 2017; 13: 2078-85. [PubMed][CrossRef]

24. Zhu FC, Li YH, Guan XH et al. Safety, tolerability, and immunogenicity of a recombinant adenovirus type-5 vectored COVID-19 vaccine: a dose-escalation, open-label, non-randomised, first-in-human trial. Lancet 2020; 395: 1845-54. [PubMed][CrossRef]

25. Sekaly RP. The failed HIV Merck vaccine study: a step back or a launching point for future vaccine development? J Exp Med 2008; 205: 7-12. [PubMed][CrossRef]

26. Jackson LA, Anderson EJ, Rouphael NG et al. An mRNA vaccine against SARS-CoV-2 - Preliminary report. N Engl J Med 2020; 383: NEJMoa2022483. [PubMed][CrossRef]

27. Gao Q, Bao L, Mao H et al. Development of an inactivated vaccine candidate for SARS-CoV-2. Science 2020;369: 77-81. [PubMed][CrossRef] 
28. Heaton PM. The Covid-19 vaccine-development multiverse. N Engl J Med 2020;383: NEJMe2O25111. [PubMed] [CrossRef]

29. Acosta PL, Caballero MT, Polack FP. Brief history and characterization of enhanced respiratory syncytial virus disease. Clin Vaccine Immunol 2015; 23: 189-95. [PubMed][CrossRef]

30. Huisman W, Martina BEE, Rimmelzwaan GF et al. Vaccine-induced enhancement of viral infections. Vaccine 20og; 27: 505-12. [PubMed][CrossRef]

31. Weiss RC, Scott FW. Antibody-mediated enhancement of disease in feline infectious peritonitis: comparisons with dengue hemorrhagic fever. Comp Immunol Microbiol Infect Dis 1981; 4: 175-89. [PubMed][CrossRef]

32. Coish JM, MacNeil AJ. Out of the frying pan and into the fire? Due diligence warranted for ADE in COVID-19. Microbes Infect 2020; S1286-4579(20)30124-6. [PubMed][CrossRef]

33. Ulrich H, Pillat MM, Tárnok A. Dengue Fever, COVID-19 (SARS-CoV-2), and Antibody-Dependent Enhancement (ADE): A Perspective. Cytometry A 2020; 97: 662-7. [PubMed][CrossRef]

Publisert: 9. september 2020. Tidsskr Nor Legeforen. DOI: 10.4045/tidsskr.20.0676

Mottatt 25.8.2020, første revisjon innsendt 30.8.2020, godkjent 2.9.2020.

(C) Tidsskrift for Den norske legeforening 2023. Lastet ned fra tidsskriftet.no 26. april 2023. 